\title{
Resenha: Voice-over Translation: an Overview
}

\author{
J ohn Milton
}

Franco, E.; Matamala, A.; Orero, P. Voice-over Translation: an Overview. Bern: Peter Lang, 2010.

Em várias visitas a Polônia nos anos de 1990, liguei a televisão no hotel e assisti às novelas mexicanas e brasileiras. Não eram nem legendadas nem dubladas. No fundo ouviam-se as vozes originais em castelhano ou português, e uma voz monótona masculina traduzia todas as falas das personagens, tanto as de crianças quanto as de senhoras. Meu polonês não era suficientemente bom para verificar a qualidade das traduções, mas a minha impressão era que fosse um tipo de tradução de péssima qualidade, com graça nenhuma e, para minha surpresa, descobri que os poloneses de fato preferem esse tipo de tradução $(50,2 \%)$ à dublagem $(43,4 \%)$, com legendagem em terceiro lugar $(8,1 \%)(p .47)$.

Essa técnica chama-se voice-over e também foi utilizada no cinema. Uma amiga polonesa me contou que, no começo dos anos 1980, ela foi assistir Greystoke, filme de Hollywood sobre Tarzan. A fita do voice-over que acompanhava o filme não funcionava, então mostraram o filme na versão original, abaixaram o volume e uma mulher com um microfone, uma pequena lâmpada e uma versão do roteiro em polonês fazia a leitura em voz alta durante a projeção do filme. Foi considerado completamente normal pela plateia.

\footnotetext{
*Professr titular do DLM/ FFLCH/ USP. Email: jmilton@usp.br.
} 
O voice-over é muito comum na televisão em vários países, especialmente em documentários: a voz original começa a falar e poucos segundos depois, o volume da voz original é baixado e entra a nova voz na língua alvo.

Eliana Franco, professora da UFBa, fez seu doutorado na Universidade de Leuven sobre voice-over ("Revoicing the Alien in Documentaries: Cultural Agency, Norms, and the Translation of Audiovisual Reality", 2000), mostrando a maneira na qual, em documentários sobre o Brasil em alemão, francês e holandês, a nova voz nem sempre faz uma tradução acurada do original, e muitas vezes altera o conteúdo, nesse caso para dar ao telespectador uma visão simplificada do Brasil, enfatizando os clichés do exotismo, da violência e da divisão de classes.

Este livro, que Eliana escreveu junto com Anna Matamala e Pilar Orero, pesquisadoras e professoras catalãs que ministram cursos de voice-over no Programa de Mestrado em Tradução Audiovisual na Universitat Autònoma de Barcelona, é um tipo de enciclopédia sobre voice-over. Um capítulo inicial relata a história e o background de voice-over. Os capítulos subsequentes são mais práticos: Capítulos 2 e 3 tratam de descrever o trabalho de fazer o voiceover de um programa já pronto, com vários exemplos; Capítulo 4 concentra-se no voice-over de entrevistas, quando não há nenhum roteiro pronto, muitas vezes feito por jornalistas; Capítulo 5 relata a experiência de montar e ministrar dois cursos em voice-over no Mestrado em Tradução Audiovisual na Universitat Autònoma; Capítulo 6 relata os resultados de uma pesquisa global sobre voice-over. O livro termina com uma extensa bibliografia comentada de 37 páginas. E cada capítulo termina com "Suggested exercises", que são muito didáticos.

No Capítulo 1 encontramos alguns dos elementos básicos de voice-over. Um elemento muito importante é o fato de que em voice-over sempre se escuta as vozes originais durante alguns segundos no começo e no fim do programa ou da entrevista e, em muitos casos, as vozes originais são mantidas durante todo o programa, mas em volume baixo. As autoras citam Francine 
Kaufmann, que chama isso de um "mecanismo ilusório" que dá a impressão que o que está sendo dito na tradução está no original. A clareza é uma característica do voice-over e, diferente da dublagem, idiossincrasias, hesitações e sotaques serão cortados.

Então, considera-se esse modo de tradução adequado para gêneros audiovisuais que retratam a "realidade", como documentários e entrevistas. E é essa característica que diferencia voice-over de "comentário", uma técnica frequentemente utilizada em filmes, onde haverá uma voz, de uma personagem ou não, que narra, reflete ou comenta a ação do filme, muitas vezes de uma visão pessoal.

O voice-over também tem semelhanças com outros tipos de tradução. É uma forma de interpretação, mas sem o elemento imediato da interpretação. Pois, em geral, o tradutor que prepara o voice-over terá certo tempo para preparar a tradução. Também tem características da dublagem sincronizada, mas não pretende criar a ilusão de ser a fala original. Outra forma de dublagem é a dublagem não sincronizada, quando a fala dublada não é sincronizada com as falas do original, mas, nesse tipo de tradução não se escuta as vozes do original no fundo.

E o voice-over pode ser combinado com outros tipos de tradução. $\mathrm{Na}$ Letônia pode-se assistir programas de televisão importados com voice-over em letão e legendas em russo. Na Televisión de Catalunya, a norma é de substituir a narração por uma narração traduzida e utilizar voice-over para entrevistas, diálogos e outras intervenções. E quando entram trechos de filmes, usa-se legendagem.

Uma versão de voice-over é a tradução Gavrilov, uma gravação de primeira mão, muitas vezes não preparada, chamada assim por causa de Andrey Gavrilov, um dos intérpretes que traduzia filmes estrangeiros para a Comissão Estadual para Cinematografia na União Soviética. Às vezes, os intérpretes tinham tempo para assistir o filme e preparar antes, mas muitas vezes tinham de interpretar o filme sem qualquer preparação prévia. As características do voice-over Gabrilov são uma voz única, geralmente 
masculina, traduzindo todas as vozes originais, que podem ser ouvidas no fundo, em um ritmo muito rápido, sem qualquer emoção. Foi esse o tipo de voice-over que escutei quando estive na Polônia. E a diferença com documentários em voice-over é que não se deixa alguns segundos do original no começo e no fim.

Mas, uma nova geração de especialistas em voice-over nem sempre segue esse tipo de tradução. Dmitry "Goblin" Puchkov é famoso por seus voice-overs engraçados, introduzindo elementos que não constam no original, e até palavrões (p.48).

Os Capítulos 2 e 3 comentam as condições de trabalho do tradutor de voice-over. Em geral, um estúdio de dublagem terceiriza o trabalho com um prazo muito limitado, muitas vezes de 48 horas, ou, no caso de uma entrevista em um telejornal, poucas horas, enviando o roteiro e/ ou o vídeo a ser traduzido por e-mail. Embora não haverá sincronização de lábios na versão final, o tradutor tem de se preocupar com a movimentação e o elemento visual (p.81). Se a pessoa na tela fala "Olha para o céu" e olha para o céu, o voice-over tem de falar essa frase na língua de chegada nesse exato momento. Assim, o tradutor de voice-over terá de fazer uma divisão de tempo do filme usando o registro de tempo, semelhante ao tradutor de legendas em DVDs.

Voice-over Translation é um livro muito bem-vindo no campo muito dinâmico da Tradução Audiovisual. Com os avanços em tecnologia, vemos mudanças constantes e a evolução de novos tipos de tradução. Há 20 anos quem ouviu falar de audiodescrição, fansub, scanlation e voice-over? 